\title{
A STUDY OF WATER USE AND WATER CONSERVATION POLICIES AT (PRIMARY) ECO-SCHOOLS IN ISTANBUL
}

\author{
SEDA TONUK ${ }^{1} \&$ KUTLU SEVINC KAYIHAN ${ }^{2}$ \\ ${ }^{1}$ Department of Architecture, Yildiz Technical University, Turkey. \\ ${ }^{2}$ Department of Architecture, Gebze Institute of Technology, Turkey.
}

\begin{abstract}
As in all building types, water conservation is important in various ways in primary education buildings that see intensive use. In addition to environmental and economic benefits, systematic application of sustainable water management in elementary education buildings also makes a positive contribution to the education of future generations. The 'Eco-Schools International Programme', which is an organization established for achieving these goals, was established in 1994 with European Union support. The programme aims to introduce environmental management systems into primary schools within the scope of ISO 14001/EMAS. It has a crucial task of educating new generations and sustainable development throughout the world. All the previous studies conducted on eco-schools indicate that they are healthier places to learn and work, they have minimal negative impact on the environment and they have lower operating costs compared to conventional schools.

This study examines elementary schools in Istanbul, which are part of the Eco-Schools International Programme. A questionnaire study was administered on the theme of water management within elementary schools located in the Asian and European parts of Istanbul city, and the findings of a field survey were examined. Questionnaire findings were gathered according to these headings under two main categories: water use and water conservation policies at outdoor environments of eco-schools (landscape water conservation measures at eco-schools, irrigation technology and irrigation timing and frequency) and water use and water conservation policies at indoor environments of the eco-schools (types of water conservative components and equipments, hot water, water and energy conservation features (eco-label) of electrical appliances and maintenance of water-related equipment). According to these topics of questionnaire study, eco-schools at Istanbul often exhibit a successful performance in terms of water conservation policies. However insufficient use of collected rainwater, treated wastewater and advanced and environmentally friendly irrigation technologies at outdoor environments of eco-schools have been observed. Similarly, it has been observed that usage of different technological enhancements towards conservative wares usage like hand-basin taps of the push-on or self-stopping types are used at a very low rate at indoor environments of the eco-schools.

Keywords: eco-schools programme, elementary schools, Istanbul eco-schools, Sustainable water consumption, water conservation.
\end{abstract}

\section{INTRODUCTION}

Water demand and consumption have increased as a result of population increase in recent years, rapid technological developments and expectations of improved quality of life. In particular, economic, political and environmental disputes about the use of potable water resources have reached great dimensions. The distribution of water, which is the source of life on earth, can be better understood by examining how restricted potable water resources are: 'Of the total amount of water on earth, 97.2 per cent is contained in salty seas, 2.05 per cent is contained in glacial icecaps, and most of the remaining 0.7 per cent is contained in aquifers. The amount of renewable fresh water, available through rainfall on watershed areas for consumption by humans, is very small, approximately 0.008 per cent of the total. Of this $110,300 \mathrm{~km}^{3}$ of water, two-thirds evaporates, leaving $40,700 \mathrm{~km}^{3}$ per year of rainwater run-off, feeding rivers and replenishing aquifers and available for domestic, industrial and agricultural use. It is on this resource, particularly, that increasing pressure is being placed' [1,2]. As Szokolay [3] said, people require very little water for daily sustenance: 'In order to survive, the human body needs only about 1 litre per day, and the average consumption of 
water in food and drink is about 2 litres per head per day. However, it is known that current per capita water consumption considerably exceeds these values'.

Using potable water and/or mains water in buildings for all general activities that consume water leads to various environmental problems. This situation is described in the book A Green Vitruvius [4]: 'Under most building codes, almost all water used in buildings must be of drinkable quality. This is drawn from the natural environment, often reducing groundwater levels and water levels in streams, lakes and marshlands. Its treatment requires the instruction and running of water treatment plants, with all the use of materials and energy that implies'. In addition, leakages from fixtures, such as taps, sinks and showers can cause significant water losses. One US study found that household leaks, such as these made up one-tenth of the water consumption of a typical household [5].

With modernization and development, water consumption from toilets and showers has become the fundamental factors for water consumption in developed countries. According to Hawken and Lovins [6], 'When using a standard flush toilet in the US we are likely to consume more water than most people in developing countries use in an entire day'. According to Graham [7], 'The average Australian WC uses between 6 and 9 litres of water per flush, although buildings built after the introduction of mandatory code requirements of dual-flush cisterns use between 3 and 6 litres per flush. The use of potable mains water in toilet reservoirs and the excessive capacity of these reservoirs lead to an increase in the amount of waste water, contamination of rivers and seas as well as depletion of water resources' Kibert [8] summarizes the situation as: 'Wastewater management in Western countries relies on a flushing system that uses precious drinking water to transport faeces out of homes and cities. Although this system resulted in a significant improvement in hygiene and health, especially in cities, during the last century, it has shifted the problem to rivers and the sea, which have been loaded with nutrients'.

Conserving dwindling water resources will be possible if consumer awareness is increased and if new water conservation strategies for all sectors are prepared and implemented. In this context, Sassi [9] categorizes strategies for conserving water in buildings as: 'There are three main approaches, relevant to building design and water-related environmental problems that contribute to reducing water use and pollution;

- First, the need for freshwater should be reduced and efficient means of using this water should be introduced in buildings.

- Second, sources of water other than mains water, such as rainwater and grey water, should be used where appropriate.

- Third, the disposal of black-, grey- and rainwater has to be considered. Pressure on the sewer and stormwater system can be reduced through rainwater retention and recycling systems, on-site wastewater treatment and SUD (Sustainable Urban Drainage) systems.

Buildings that can combine all three approaches are well on their way to becoming water autonomous. Water autonomy implies a provision of freshwater independent from mains supply and on-site sewage and storm-water treatment and disposal, obviating the need for a sewer connection'. The steps to be implemented in buildings to ensure water autonomy are: 'Installing water-efficient appliances and fixtures, using drought resistant plants in landscaping and changing irrigation practices can reduce water consumption by 30 percent or more' [10]. To reduce the dependency on mains water, rainwater and grey water, which are under-utilized resources, can be used for activities not requiring potable water. A number of researchers have commented on the use of rainwater and 
grey water: 'Greywater that has been cleaned by removing particles, disinfecting it, and possibly improving its appearance, can be reused for watering the garden, flushing WCs and washing laundry: this can save up to 40 per cent of water needs' [9]; 'Green buildings conserve and recycle water in a variety of ways. Rain water is captured and used for plants and flushing toilets; 'grey water' from showers, baths and basins is also used to flush toilets or repurified through reedbeds that are part of the buildings' landscaping' [11].

The abovementioned water conservation and management policies and similar precautions can only be provided if the issue is presented in laws and regulations, supported by research and greater public awareness. In Collaborative for High Performance Schools (CHPS), which is one of the most important studies carried out on sustainable school buildings, the following environmental, economic and educational benefits are emphasized: 'Basic efficiency measures can reduce a school's water use by $30 \%$ or more. These reductions help the environment, locally and regionally. They also lower a school's operating expenses. The technologies and techniques used to conserve water-especially landscaping, water treatment, and recycling strategies-can be used to help instruct students about ecology and the environment' [12].

It is known that awareness campaigns on environmental issues, especially for elementary school students who are the future of the society, are carried out in developed countries; school buildings are an appropriate site for conducting such awareness-raising studies. In this context, there are many organizations established to reduce the negative environmental effects of school buildings, addressing various issues, such as energy, water, and waste, and increasing students' environmental awareness. This includes the EU Eco-Schools Programme, which is applied successfully in many countries around the world. A large number of schools in Turkey are members of the Eco-Schools Programme.

The purpose of the research is to evaluate water use and water conservation studies carried out in primary-grade eco-schools in Istanbul, which is the most populous city in Turkey. The scope of the research was determined as follows:

- Determining water use and water conservation policies, especially for irrigating plants in outdoor environments.

- Evaluating water use and water conservation in wet areas in indoor environments (WC, shower, kitchen etc.).

Before evaluating water conservation within eco-schools in Istanbul Province, it is useful to briefly discuss water consumption in Turkey. Annual per capita water resource potential in Turkey is

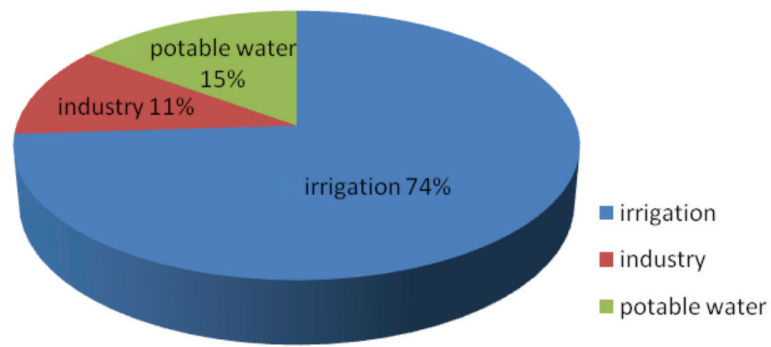

\begin{tabular}{|lr|}
\hline irrigation: & 34 billion $\mathrm{m}^{3}$ \\
industry: & 5 billion $\mathrm{m}^{3}$ \\
potable water: & 7 billion $\mathrm{m}^{3}$ \\
total: & $\mathbf{4 6}$ billion $\mathbf{~ m}^{\mathbf{3}}$ \\
\hline
\end{tabular}

Figure 1: Water consumption by sector in Turkey [13]. 
$1600 \mathrm{~m}^{3}$. A country with per capita water potential of $5000 \mathrm{~m}^{3}$ or more is accepted as 'water-rich' [13]. Water consumption by sector in Turkey as of 2008 is shown in Fig. 1, below.

Nearly all of Istanbul's drinking water (97\%) comes from surface water collected in reservoirs. Its most important water sources are the Omerli-Darlik system on the Asian side and the Terkos-Alibeykoy system on the European side. Both systems consist of dams, reservoirs, water treatment plants, and pipelines. Many of the reservoirs that supply Istanbul are located within the metropolitan area and are exposed to pollution from settlements without adequate sanitation. Water quality is theoretically controlled by conservation zones around the reservoirs which limit construction and industrial activities in four concentric buffer zones with increasingly strict regulations to zones which are closer to the reservoirs. However, there is little enforcement of these regulations in the face of rapid and often unplanned urbanization $[14,15]$.

However, given the growth of Istanbul, additional water resources were still needed. Therefore, the Melen system is being developed to cover the long-term water demand of Istanbul. The first stage supplying 268 million $\mathrm{m}^{3}$ was completed in 2007 with Japanese financing. A second and third stage are expected to bring a total of 1,180 billion $\mathrm{m}^{3}$ for all three phases to meet the water demand of the city until the year 2040, doubling the amount of water supplied prior to the Melen system [16]. According to the monitoring by four metropolitan agencies, the drinking water quality is good, reportedly surpassing Turkish as well as EU standards. According to a 2004 survey, 35\% of customers stated that they drink water from the tap, up from only $10 \%$ in 2000. During that period, water quality had improved due to network repairs and the completion of new drinking water treatment plants [17].

In Istanbul Province, in which the research was conducted, average annual water consumption is $45 \mathrm{~m}^{3}$ per capita [18]. Any statistics about water availability and consumption at eco-schools declared by Istanbul Ministry of Education or any other related institution could not be reached.

The optimal water consumption values in the school buildings are as follows: 'A generally accepted benchmark figure for water use in primary/secondary schools is 4 cubic metres/pupil/ annum. This figure will increase if a school has a swimming pool and/or community use' [19].

\section{MATERIALS AND METHOD}

The city selected for the present research, Istanbul, is the most crowded and economically most important city of Turkey. Having the 34th largest economy of the world, Istanbul is the most crowded city of Europe as well. In this scope, data to be produced by the studies which will be conducted in Istanbul will reflect whole Turkish case at a significant level.

Directly proportional to economic development level and population, the number of educational institutions in Istanbul is higher than that of the education institutions in other cities of Turkey. Moreover, great majority of the schools involved in eco-schools programmes are in Istanbul. By the end of 2009, Istanbul had 55 schools participating in the eco-schools programme. Questionnaires were distributed to these 55 schools and 37 (67\%) schools had completed the questionnaire study. The distribution of participating schools located in the European and Asian sides of Istanbul is shown in Fig. 2.

The present research used a structured review method. This is a quantitative research method that is used in survey studies. A previous study called 'Formal Environmental Review' [20], produced by the eco-schools international programme, was used as the basis when preparing the questionnaire. However, the questionnaire was revised according to the characteristics of the research site, in accordance with suggestions from the eco-schools programme. An open-ended question was addressed so as to take additional comments in the questionnaire study generally comprising of closed questions. Questionnaire ${ }^{1}$ forms were emailed to eco-schools coordinators and administrators 


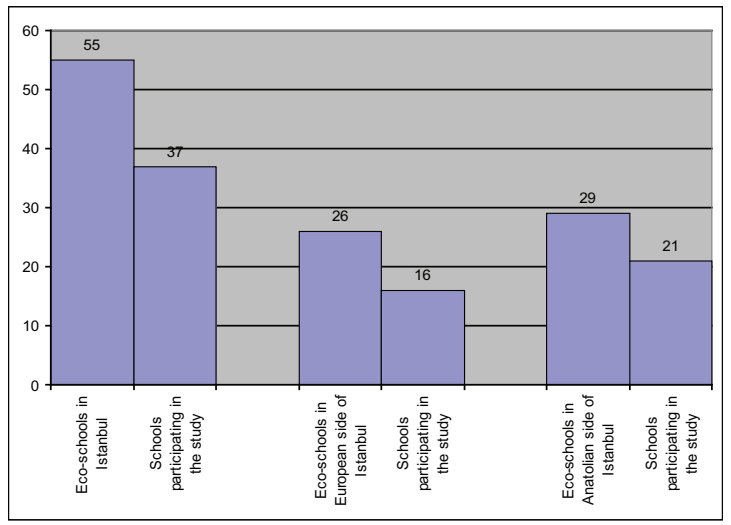

Figure 2: Distribution of participating eco-schools in Istanbul.

in private and state elementary schools in Istanbul that participated in the eco-schools programme. Contact information of related coordinators and administrators was provided by the National Coordinator of Eco-Schools [21] of the Turkish Foundation for Environmental Education, which is the representative of the eco-schools international programme in Turkey. Filled in Questionnaires and returned by 37 schools constituted the database of the present research (see Diagram 2). Frequency analysis tool of SPSS statistics software was utilized for analyzing the questionnaire results.

This research has been conducted with the permission of İstanbul Province National Education Directorate (IPNED), which is a subordinate of Ministry of National Education in Turkey. During discussions with IPNED and Environment and Education Foundation of Turkey (EEFT), it has been verified that this is the first study ever conducted in this field; thus, we believe that it is an original study. Since it is the first research in this field and in this region, there are no previous researches to relate to. EEFT is the representative of Eco-Schools International Programme and they have requested the results of our finding to create new guidelines for future.

\section{ECO-SCHOOLS INTERNATIONAL PROGRAMME}

Eco-Schools is a programme for environmental management and certification, designed to implement sustainable developmental education in schools by encouraging children and youths to take an active role in how their school can be run for the benefit of the environment.

The Eco-Schools International Programme was developed as a response to some of the needs identified at the UN Conference on Environment and Development in 1992. The Programme started in 1994, with the support of the European Commission (DG XI and DG XXII), in four countries: Denmark, Germany, Greece and United Kingdom. In 1999, the organization received the 'Worldaware Award for Global Education' from the North-South Centre of Council of Europe and NCDO. In 2003, Eco-Schools was identified by the United Nations Environment Programme (UNEP) as a model initiative for Education for Sustainable Development [22]. Today, 52 countries are members of the eco-schools programme and Turkey is one among them [23]. As it can be seen in Fig. 2, there were 55 schools participating in the eco-school programme at the date of the research. There are 1,515 public and private schools in Istanbul [24] [25].

The Eco-Schools Programme employs a holistic, participatory approach, combining learning and action, thus providing an effective method for improving the environments of schools, raising 
awareness and producing behavioural change in young people, school staff, families, local authorities and others with a significant influence within local communities. Eco-Schools Programme is one of the programmes of the FEE - Foundation for Environmental Education (www.fee-international.org) and, as such, it is implemented through FEE Member organizations (one per country). Currently, the Programme is being implemented in 47 countries around the world, involving 32,156 schools $(9,898$ of which have already been awarded with various eco-schools certificates), 9,125,460 students, 628,005 teachers and 5,013 local authorities. The Eco-Schools Programme is based on ISO14001:2004 . The Eco-Schools methodology encompasses seven steps that any school can adopt [22].

The Eco-Schools Committee is the driving force of the Eco-Schools process and the first step towards becoming an Eco-School. The committee directs the operations of a school's Eco-Schools programme. There is no one particular way how the committee is set up. It might evolve from a group that is already active in the school or it can be set up from scratch through nominations from the head of school or the pupils. An ideal Committee will also represent the views of the wider, local community as well as the whole school [22].

In Step 2, work begins with a review or assessment of the environmental impact of the school. The results of the school's Environmental Review will be essential to build the Action Plan, assisting the school to decide whether any change is necessary, urgent, or not required. The Review also helps schools to set realistic targets and measure their success. Schools may first quantify their impacts for the theme they are working on or cover all the areas in which the school may have environmental impacts, namely: waste management, waste minimization, school soils, biodiversity, energy, water, transport, health and well-being and sustaining the world [22].

The action plan, which is created in Step 3 of the process, is the core of the Eco-Schools work and is developed using the results of the environmental review [22].

\subsection{Water conservation strategies at Eco-Schools international programme}

The Eco-Schools Programme contains a number of 'themes', and provides the following information and recommendations on the issue of water management:

The Eco-Schools Programme provides an introduction to the importance of water both locally and globally and raises awareness of how simple actions can substantially cut down water use. Schools can reduce their water consumption by assessing how much they use every day and by looking at the size of their meter, identifying leaks and drips, adapting the flow rate on taps and reducing the amount of water used in toilets. Many eco-schools have addressed water and utility costs as part of their action plan. Careful water management together with an effective education programme can reduce water use by two-thirds [22].

The availability of clean, fresh water is one of the most important issues facing humanity today and will be increasingly critical for the future as growing demands outstrip supplies and pollution continues to contaminate rivers, lakes and streams. To raise awareness and galvanize actions to better manage and protect this crucial resource, the United Nations General Assembly has proclaimed 2003 as the International Year of Freshwater. Eco-Schools worldwide have joined UNEP in its efforts to help safeguard the most precious source of life on our planet [22].

\section{CASE STUDY}

Communication was established with eco-schools coordinators and administrators in these schools via e-mail, and questionnaire comprising of 12 questions in the topics of water use and water conservation was implemented. The main themes of the questionnaire study are 
- Water conservation policies at outdoor environments of eco-schools (water-efficient irrigation, irrigation technology, irrigation timing and frequency)

- Water conservation policies at indoor environments of the eco-schools (types of water conservative components and equipments, water and energy conservation features (eco-label) of electrical appliances, maintenance of water-related equipment).

\subsection{Water use and conservation strategies at outdoor environments of eco-schools}

Garden irrigation is an important parameter for eco-schools in monitoring water consumption in outdoor environments. In this context, guidance on the operating policies of eco-schools is available from various resources: 'Outdoor water use varies widely from place to place and climate to climate but, on average, 50 percent of water use occurs outside. There is a tremendous opportunity to conserve water through appropriate landscaping design, operation, and maintenance' [10].

The following information about landscape and water consumption comes from the Washington Sustainable Schools guide: 'Design landscaping to use water efficiently by reducing water use and specifying hardy, native vegetation... Where irrigation is used, use high efficiency irrigation technology (e.g., drip irrigation in lieu of sprinklers). If local climate allows, use captured rain or recycled site water for irrigation and "design in" cisterns for capturing rainwater' [26].

Water conservation strategies for irrigation in schools are categorized in the Eco-Schools Programme as

- Preferring plant types, during landscape planning, which do not need much water;

- Irrigating only during times of need and using automatic irrigation with moisture sensor systems;

- Grouping similar plant types according to their water requirements (hydro-zoning). Mulching reduces water evaporation. Improving soil condition with organic material improves water retention [27].

\subsubsection{Criteria for landscape and irrigation}

Creating water-use budgets is envisaged as a prerequisite for water conservation criteria within outdoor irrigation strategies in CHPS guides to manage demand for irrigation water and comply with local water efficient landscape ordinance. In addition to this item, another criterion includes the following information: 'Reduce potable water, natural surface water or groundwater consumption for irrigation by $50 \%$ over landscape budget baselines with the use of water-efficient native (or adapted) climate-tolerant plantings, high-efficiency irrigation technologies, or using captured rain or municipally provided reclaimed water' [28].

The following information is given in the 'Water Efficient Landscaping' section of the 'LEED for Schools' guide, which is a green building certification system adopted in many countries: 'Reductions must be attributed to any combination of the following items: plant species, density

Table 1: Landscape water conservation measures at eco-schools in Istanbul.

\begin{tabular}{lccl}
\hline Question & Answer & Yes & No \\
\hline Are landscape water conservation & Frequency & 7 & 30 \\
measures implemented? & $\%$ & 18.9 & 81.1 \\
\hline
\end{tabular}


and microclimate factor, irrigation efficiency, use of captured rainwater, use of recycled wastewater, use of water treated and conveyed by a public agency specifically for nonpotable uses' [29].

It was found that $81.1 \%$ of eco-schools in Istanbul adopted strategies for water conservation in landscaping, and based on the proportions, it is thought that a success was achieved in this area. However, it is seen that schools achieved relatively little success in conservation of potable water and reducing its use for irrigation.

According to the findings of the research, the reason why wastewater is used less than mains water is that there are not enough wastewater plants in Turkey and wastewater use is not generally utilized by society. The use of artesian, well water and rainwater sources is widespread in Turkey. However, the usage and/or preference for these types of water resources in eco-schools in Istanbul are not common. This result is inconsistent with the general tendency. Within the present research, only Hisar Educational Foundation Kemerköy Schools used well water in toilets and garden irrigation.

In addition, climatic conditions should be considered when evaluating outdoor irrigation in eco-schools. Istanbul Province is located in a humid and rainy climate zone and data from the previous 50 years shows that the average annual rainfall Istanbul is $700 \mathrm{~mm} /$ year [13]; it is therefore important to particularly encourage the use of rainwater. Locating rainwater collection systems in the school garden where students can see them is very significant in promoting the tendency of students towards water conservation.

\subsubsection{Irrigation technology}

A significant amount of water sprayed during irrigation is mixed into the air by means of evaporation, and thus optimum benefit cannot be achieved from these forms of irrigation. In addition, a garden sprinkler uses as much water in half an hour as a family of four in one day [27]. The most efficient solutions to these problems are time-adjusted drip root irrigation system or subsurface root irrigation systems. The following information about irrigation systems is provided in the BREEAM Education guide [30]:

1. Where the irrigation method specified for internal or external planting and/or landscaping complies with anyone of the following

- Drip-feed subsurface irrigation that incorporates soil moisture sensors. The irrigation control should be zoned to permit variable irrigation to different planting assemblages.

- Reclaimed water from a rainwater or grey water system.

- External landscaping and planting that relies solely on precipitation, during all seasons of the year.

- The only planting specified is restricted to species that thrive in hot and dry conditions.

2. Where a subsurface drip-feed irrigation system is installed for external areas, a rainstat must also be installed to prevent automatic irrigation of the planting and the landscape during periods of rainfall.

Table 2: Distribution of water resources used for irrigation at eco-schools in Istanbul.

What kind of water use for irrigation at your school?

Frequency

Mains water

Waste water

Accumulated rain water

Other

$\begin{array}{cr}21 & 56.7 \\ 10 & 27.0 \\ 4 & 10.8 \\ 1 & 2.7\end{array}$


Table 3: Irrigation technologies used at eco-schools in Istanbul.

\begin{tabular}{lcc}
\hline Which irrigation technology is used at your school? & Frequency & $\%$ \\
\hline Manual irrigation & 29 & 78.4 \\
Sprinkler-type irrigation & 14 & 37.8 \\
Drip irrigation & 4 & 10.8 \\
\hline
\end{tabular}

Table 4: Irrigation technologies used at eco-schools in Istanbul.

\begin{tabular}{lccc}
\hline Questions & Answers & Yes & No \\
\hline Is there a time setting on the & Frequency & 8 & 29 \\
irrigation system? & $\%$ & 21.6 & 78.4 \\
\hline
\end{tabular}

Table 5: Timing of irrigation at eco-schools in Istanbul.

\begin{tabular}{lccc}
\hline Questions & Answers & Night & Day \\
\hline Which time is irrigation done & Frequency & 24 & 13 \\
at your school? & $\%$ & 64.9 & 35.1 \\
\hline
\end{tabular}

Table 6: Garden irrigation frequency at eco-schools in Istanbul.

\begin{tabular}{lcc}
\hline What frequency are outdoor plants require watering? & Frequency & $\%$ \\
\hline Everyday & 6 & 16.2 \\
Every other day & 10 & 27.0 \\
Once in 3 days & 14 & 37.8 \\
Once a week & 7 & 18.9 \\
Total & 37 & 100.0 \\
\hline
\end{tabular}

The fact that drip-root irrigation system, which is the ideal method in irrigating green areas, is used with a ratio of $10.8 \%$ indicates that in most eco-schools in Istanbul water is not used in an economical and conscious way. In addition, considering that the use of time-adjusted irrigation systems was quite low (21.6\%), it is clear that there is a need to review the outdoor water-use strategies in eco-schools. In this context, it is recommended that modern irrigation technologies be installed in eco-schools to achieve economic use and control of water in outdoor applications.

\subsubsection{Irrigation timing and frequency}

The ideal times for landscape irrigation are early morning and evening, when evaporation will be minimized. The US Environmental Protection Agency (EPA) lists the following irrigation criteria for water conservation in schools: 'If you water your lawn and flower beds, only do it once a week, if rainfall isn't sufficient. Avoid watering on windy and hot days. Water the lawn and flowerbeds in the morning or late in the evening to maximize the amount of water that reaches the plant roots 
(otherwise most of the water will evaporate). When you water, put down no more than 1 inch (set out a empty cans to determine how long it takes to water 1 inch) each week. This watering pattern will encourage more healthy, deep grass roots' [31].

Since most schools do not have time-adjusted irrigation systems (see Table 4), it is thought that day watering, reported in $35.1 \%$ of schools, is connected with the working hours of schools. When the irrigation frequency is examined for green outdoor areas, it is observed that all of the four options were used. It is seen that relatively few eco-schools $(18.9 \%)$ conduct irrigation once per week, as recommended by the EPA. It can therefore be assumed that green areas in most of the eco-schools $(81.1 \%)$ are irrigated more frequently than specified in EPA criteria. However, since the size of the schools participating in the research and the plant types in their gardens are not known, there is no way to recommend a method for these schools.

\subsection{Water conservation strategies at indoor environments of the eco-schools}

Choosing water-efficient equipment, such as toilets, taps, sinks etc., is one of the most important strategies for water conservation in indoor environments. Similar water-efficient products are recommended to be used in eco-schools. The features of currently available water-efficient toilets are categorized as follows:

- While dual-flush cisterns consume 3-6 L of water during a complete flush, they consume 1.5-4 L of water during a half flush.

- Vacuum toilets work with air instead of water. However, since they work with electricity, they increase energy consumption while conserving water.

- Waterless/composting toilets - whether or not they have electric dryer features - reduce water consumption by $40 \%$,

- Urine-separating toilets consume very small amounts of water in comparison with dual-flush and low-flush toilets [32].

The characteristics of water-efficient taps are categorized as follows:

- Aerated taps, consume less water than standard taps by mixing water with air. While standard taps consume $20 \mathrm{~L}$ of water per minute, aerated taps consume $3.6 \mathrm{~L}$ of water per minute.

- Flow regulators restrict the amount of water reaching the tap. The flow of water can be adjusted, if necessary.

- Automatic basin taps with infrared sensors activate the water flow when a hand is detected under the tap and then automatically stop.

- Self-closing taps are pushed to activate and turn off automatically after a set time [32].

In addition to using water-efficient devices and equipments in primary education buildings, it is also important to integrate water meters, which allow users to monitor the water consumption in the points which can be seen by users. Accordingly, 'Policies to encourage water meters to be installed in prominent locations are suggested to allow ease of monitoring. Low water-use appliances, such as toilets, washers, showers and spray taps, should be installed to help reduce consumption' [32]. The BREEAM Education guidance includes details of water meters:

- The specification of a water meter on the mains water supply to each building; this includes instances where water is supplied via a borehole or other private source. 
- The water meter has a pulsed output to enable connection to a Building Management System (BMS) for the monitoring of water consumption [30].

\subsubsection{Water-efficient equipment usage at indoor environments}

The fundamental aim of implementing water conservation in eco-schools is to gradually reduce water consumption. In relation to this issue, the objectives and criteria on reducing water consumption in 'sustainable building certification systems' for schools are given below.

Water conservation precautions in schools in CHPS:

- Reduce sewage conveyance from toilets and urinals: Reduce wastewater generated and the use of potable water. Reduce the use of municipally provided potable water for toilets and urinals by a minimum of $50 \%$ through the utilization of water-efficient fixtures and/or using municipally supplied reclaimed water.

- Reduce potable water use: Reduce the use of potable water supplied by municipal water systems. Reduce indoor potable water consumption for uses other than toilets or urinals by $20 \%$ beyond the baseline established by the Energy Policy Act of 1992 [28].

Reducing water consumption in LEED for Schools:

- Water use reduction: To increase water efficiency within buildings to reduce the burden on municipal water supply and wastewater systems. Employ strategies that in aggregate use $20 \%$ less water than the water use baseline calculated for the building (not including irrigation) [29]. Water consumption in BREEAM Education:

- Water consumption: Reduce indoor potable water consumption for uses other than toilets or urinals by 30\% beyond the baseline established by the Energy Policy Act of 1992 [30].

The research found that guidance on water efficiency was implemented in $75.7 \%$ of eco-schools. However, it was also seen that the precautions in question were implemented in different categories. Applying all of the water efficiency technologies in cisterns and sinks used by students, teachers and personnel during the day will be an important step for economical and conscious use of water in wet areas. In particular, installing sensor-controlled lavatory combination faucets in all schools in place of conventional combination faucets should be a priority.

Table 7: Water-efficient equipment usage at indoor environments of eco-schools in Istanbul.

\begin{tabular}{lccc}
\hline Questions & Answers & Yes & No \\
\hline Are water conservation measures being & Frequency & 28 & 9 \\
implemented at indoor environments? & $\%$ & 75.7 & 24.3 \\
Are the reservoirs and taps used at your school & Frequency & 27 & 10 \\
have water loss minimizing properties & $\%$ & 73 & 27 \\
(low-flow, sensor, etc.)? & & 9 & 28 \\
Are hand-basin taps of the push-on or & Frequency & $\%$ & 75.7 \\
self-stopping type? & $\%$ Frequency & 19 & 18 \\
Are there low-flow and timer shut-off devices & $\%$ & 51.4 & 48.6 \\
at your school's shower heads? & & & \\
\hline
\end{tabular}


Table 8: 'Eco-label-A Class' property on electrical appliances at eco-schools in Istanbul.

\begin{tabular}{lclc}
\hline Questions & Answers & Yes & No \\
\hline $\begin{array}{l}\text { Do the washing machines and dishwashers } \\
\text { have 'eco-label-A class' in your school? }\end{array}$ & Frequency & 29 & 8 \\
\hline
\end{tabular}

\subsubsection{Water conservation features (eco-label) of electrical appliances}

Within Europe, washing machines and dishwashers are categorized with an 'eco-label' from A (most efficient) to $\mathrm{G}$ (least efficient). Water-efficient machines consume approximately $50 \mathrm{~L}$ of water during a washing cycle, compared with older models, which may consume $100 \mathrm{~L}$ or more. In this context, 'A Class' machines are recommended to be used in buildings.

The finding that $78.4 \%$ of eco-school cafeterias and dining halls had eco-efficient appliances was assessed as an up-to-date approach. However, it is recommended that eco-efficient appliances be installed at all schools in time.

\subsubsection{Maintenance of water equipments}

The performance of water systems and equipment in schools can deteriorate over time, or water losses may occur due to wear. Regular, scheduled maintenance of water equipment - without waiting for problems to arise - ensures the prevention of such water losses. In addition, other precautions that can be taken are summarized in the following list:

- Read and monitor your meter regularly, and compare with your bill;

- Check for leaks and dripping taps, and encourage pupils to report them, water leaks can get out of hand and increase your bill very quickly;

- Check urinal controls and ensure they are not left running when not in use at night or during school holidays [19].

The BREEAM Education guide provides further water conservation criteria for schools, related to maintenance and operational factors:

- A leak detection system capable of detecting major leaks on the water supply has to be installed. The system must cover all mains water supply between and within the building and the site boundary.

- The leak detection system is:

1. Activated when the flow of water passes through the water meter/data logger at a flow rate above a pre-set maximum for a pre-set period of time,

2. Able to identify different flow and therefore leakage rates, for example, continuous, high and/or low level, over set time periods [30].

Table 9: Indoor water conservation strategies being implemented at eco-schools in Istanbul.

\begin{tabular}{lccc}
\hline Questions & Answers & Yes & No \\
\hline Is the maintenance of water-using & Frequency & 34 & 3 \\
equipment being done regularly? & $\%$ & 91.9 & 8.1 \\
\hline
\end{tabular}


It was found that $91.9 \%$ of eco-schools conducted regular maintenance of water equipment, thereby preventing water losses. As well as efficient and conscious use of water, preventing water losses is also an important issue for sustainable water management. In this context, along with regular maintenance of water systems, installing leak detection systems in eco-schools will be an important approach.

Further to the water conservation strategies presented in the tables above, several eco-schools had implemented additional water-efficiency measures. ${ }^{2}$

In Doğa College, water bills were collected and presented on notice boards in the classes. Also, slogans about the conscious use of water were placed on notice boards and the corridors of the school were decorated with water drops. The students completed a 'Water Detective Study', designed to raise their awareness of water consumption. World Water Day (22 March) was celebrated with students from 7 primary schools and 15 nursery schools by inviting world-renowned Japanese researcher Hometo, who effects water crystals. Sensitivity towards water was emphasized by means of press and media. Conscious water consumption was promoted by applying questionnaires to students and parents. Students prepared warning notes in the shape of water drops, which they hung on door handles in their neighbours' letterboxes and the windscreen wipers of cars. The students prepared projects about water and made presentations; water dances and water competitions were arranged. All the studies carried out are published on the school's website. Within the scope of the Eco-Schools Programme, an information programme is conducted in Uğur College at the beginning of each academic year for all administrators, teachers, personnel and students. In a floor of Atacan Primary School, there is a model of a fountain with the eco-code of the school hung on it. An ecocode display board located on the first floor presents information about the school's water savings each year. In addition, studies and presentations are carried out with students periodically to review the school's progress on the issue and share new information. At Uskudar Doga College, it was reported that parents were included in studies about energy- and water-saving issues. Students bring water bills from their homes, which were categorized according to their months and the family making the greatest water saving is given an award.

\section{CONCLUSION AND FINDINGS}

Before proceeding to the findings of the research, feedback comments to the literature mentioned at the beginning of the research shall be given. It has been concluded in this field research that most of these echo-schools are using potable/mains water. However, usage of potable water and/or mains water in buildings for all general activities that consume water leads to various environmental problems as described in the book A Green Vitruvius and in various different sources.

According to THERMIE Program of the European Commission [4], grey water is suggested to be used specially on watering outdoor areas; however, according to Table 2, it can be seen that usage of grey water is very low (27\%) in eco-schools. According to Collaborative for High Performance Schools [12,] by taking simple precautions at schools, there can be $30 \%$ or more savings on water consumption. But it has been verified with the eco-schools taking part of this research that re-usage of rain and waste water is very poor.

Schools of countries having different development levels can participate in the Eco-Schools Programme. In this scope, it is impossible to achieve an equivalent level of success in terms of waste management in all eco-school members. However, works related to documentation of the activities carried out by the member schools of the Eco-Schools Programme, in the scope of the programme, will enable the local and global comparisons of these schools. Obtained data will reveal strengths and weaknesses of these schools and will enable making of future projections on these issues. 
The questionnaire study, during which water management of the schools - located in Istanbul and member to Eco-Schools Programme (55 schools) - was questioned, tried to find out the strengths and weaknesses of the schools which participated in the research ( 37 schools). Based on the findings of the present research, the following recommendations can be made for the progression of ecoschools in Istanbul:

- In the context of the findings in Table 2: Distribution of water resources used for irrigation at eco-schools in Istanbul:

(i) Installing necessary technological systems (rain water collection systems) required for garden irrigation in eco-schools in Istanbul Province, which is located in a humid and rainy climatic zone;

(ii) Encouraging the widespread use of artesian and well waters for irrigation of eco-schools in Istanbul Province;

- Considering the findings in Table 3: Irrigation technologies used at eco-schools in Istanbul, it is recommended that eco-schools install drip irrigation systems for garden irrigation, as these systems have the lowest water losses;

- Within the scope of the finding in Table 4: Irrigation technologies used at eco-schools in Istanbul, it is recommended that eco-schools use time-adjusted garden irrigation systems;

- Considering the finding in Table 5: Timing of irrigation at eco-schools in Istanbul, garden irrigation in all schools should be done during the evening, when the water loss resulting from evaporation is minimized;

- According to the findings in Table 6: Garden irrigation frequency at eco-schools in Istanbul, school gardens should use plant types that do not require much water and which are in harmony with local vegetation; also within this theme are schools that are not carrying out excessive irrigation in green areas.

The findings of the research indicate that there are important shortcomings in water use and water management issues in outdoor environments within the Istanbul eco-schools that participated in the questionnaire study. Although the results show that eco-schools use and manage water better in indoor environments, there remain areas for improvement, which are detailed below:

- According to the findings in Table 7: Water-efficient equipment usage at indoor environments of eco-schools in Istanbul,

(i) All schools should install sensor-controlled lavatory combination taps, which are currently only used in very few cases.

(ii) Priority should be given to installing aerated shower heads with low flow and self-closing features.

Although it was not present in the questionnaire study, it is recommended that a leak detection system should be installed in wet areas to prevent water losses that cannot otherwise be identified in water system and equipment.

Considering the general results, it is recommended:

- To gradually apply the same or similar applications in all elementary schools in Turkey and Istanbul,

- To add educative seminaries and/or compulsory lessons on the topics of 'environment', 'environmental awareness', 'water management' to the curriculum in addition to basic education 
subjects;

- To seek active support from professionals in the fields of 'education' and 'environment and water management' (universities, those working in applied fields, non-governmental organizations, provincial governments etc.);

- To implement student activities on water and water management issues within certain programmes and with the cooperation of all schools.

\section{ACKNOWLEDGEMENTS}

The authors are grateful to Istanbul Ministry of National Education, Istanbul Provincial Directorate for National Education, Turkish Foundation for Environmental Education (TÜRÇEV), National Coordinator of Eco-Schools, coordinators and administrators of eco-schools participating in the research for their valuable contributions and supports.

\section{NOTES}

${ }^{1}$ Results of the questionnaire study which is conducted under the approval and permission of Istanbul Provincial Directorate for National Education (IMEM) have to be published and these publications have to be delivered also to IMEM.

${ }^{2}$ The necessary permission to publish school names in academic studies and publications conducted and to be conducted on eco-schools in Istanbul was received from the National Coordinator of the Turkish Foundation for Environmental Education (TURÇEV) Eco-Schools Program via e-mail in April, 2010.

\section{REFERENCES}

[1] Mackenzie, F.T., Our Changing Planet: An Introduction to Earth System Science and Global Environmental Change, 3rd edition, Prentice Hall: New York, pp. 580, 2003.

[2] Postel, S., Dividing the Waters. MIT's Technology Review, 100(3), USA, 1997.

[3] Szokolay, S.V., Environmental Science Handbook, The Construction Press: London, pp. 421, 1980.

[4] THERMIE Program of the European Commission within a project involving the ERG, UCD and etc., A Green Vitruvius. James and James Ltd: London, pp. 41, 1999.

[5] US Water News, Leakage Varies World Wide. Natural Capitalism: creating the next industrial revolution, P. Hawken, A. Lovins \& L.H. Lovins, (1999), Little, Brown \& Co: New York, Chapter 11, pp. 18, 1992.

[6] Hawken, P., Lovins, A. \& Lovins, L.H, Natural Capitalism: Creating the Next Industrial Revolution, Little, Brown \& Co: New York, Chapter 11, 1999.

[7] Graham, P., Building Ecology, Blackwell Science: Oxford, pp. 72, 2003.

[8] Kibert, C.J., Sendzimir, J. \& Guy, B. (eds.), Construction Ecology: Nature as the Basis for Green Buildings, Spon Press: London, pp. 210, 2002.

[9] Sassi, P., Strategies for Sustainable Architecture, Taylor \& Francis: New York, pp. 257, 2006.

[10] Poudre School District Sustainable Design Guidelines. (2005). pp. 3-35, www.psdschools. com/...design.../sustainable_design_guidelines_2005.pdf

[11] Buchanan, P., Ten Shades of Green Architecture and the Natural World, The Architectural League of New York: New York, pp. 32, 2005.

[12] Collaborative for High Performance Schools, (2004). Best Practices Manual. Volume VII - 1., Eley Associates, San Francisco, CA, p. 17, 2004, http://www.chps.net/content/032/CA_ CHPS_Criteria_2009.pdf

[13] General Directorate of State Hydraulic Works, Turkey, http://www.dsi.gov.tr/topraksu.htm 
[14] Demirci, A., Butt, A., Historical Overview and Current Trends in Istanbul's Water Supply Development, Globalization and Water Resources Management: The Changing Value of Water, August 6-8, Awra/Iwlri-University of Dundee International Specialty Conference 2001, UK.

[15] Kara, S., Alleweldt, F., Trinwasserversorgung und Stadtexpansion: Der Fall Istanbul (Drinking Water Supply and Urban Expansion:The Case of Istanbul), in: Wasser - Abwasser 136 (1995), Nr. 7, pp. 345-353.

[16] XIVst Regional Directorate of State Hydraulic Works -Istanbul, Melen Project, http://www2. dsi.gov.tr/english/region/14st.htm

[17] Altinbilek, D., Water management in Istanbul. International Journal of Water Resources Development, 22(2), pp. 241-253, 2006.

[18] Istanbul Water and Sewage Authority, http://www.iski.gov.tr/web/haberDetay.aspx? $\mathrm{HID}=1001297$

[19] Hampshire County Council, http://www3.hants.gov.uk/sustainableschools/sustainableschools-action/sustainable-schools-energy.htm

[20] Formal Environmental Review, 2012, http://www.ecoschoolsni.org/media/Environmental\%20 review\%20form.pdf

[21] Turkey Foundation for Environmental Education, www.turcev.org.tr

[22] Eco-Schools International, http://www.eco-schools.org

[23] Eco-schools International, Countries: http://www.eco-schools.org/countries_contacts.php

[24] Private Primary Schools in Istanbul, http://www.webrehberi.biz/3-1-14/istanbuldaki-ozelilkogretim-okullari.aspx

[25] Turkey Ministry of Education, National Education Directorate Istanbul, http://istanbul.meb. gov.tr/Okullar.aspx

[26] Frumkin, H., Geller, R.J. \& Leslie Rubin, I., (eds.), Safe and Healthy School Environments, Oxford University Press: New York, pp. 343, 2006.

[27] Foundation for Environmental Education International, Eco-schools, 2011, http://www.ecoschools.org

[28] California Criteria for High Performance Schools, Best Practices Manual: Criteria for New Constructions and Major Modernizations, Volume III., California, pp. 51-59, 2009. http://ecoelpaso.org/presentations/txchps_criteria_prepublic_10_10_08.pdf

[29] USGBC, LEED 2009 for Schools New Constructions and Major Renovations, USA, pp. 23, 2010, http://www.usgbc.org/ShowFile.aspx?DocumentID=7248

[30] BRE Environmental Assessment Method (BREEAM) Education, Scheme Document SD 5051, BRE Global Ltd: Watford, pp. 210, 2008. http://www.breeam.org/page.jsp

[31] US Environmental Protection Agency (EPA), http://www.epa.gov/region01/eco/drinkwater/ water_conservation_schools.html

[32] Pitts, A., Planning and Design Strategies for Sustainability and Profit: Pragmatic Sustainable Design on Building and Urban Scales, Elsevier Architectural Press: Boston, pp. 50, 2004. 